\title{
Forests burnability in Siberian subregion and post-fire effects according to modern and retrospective satellite surveys
}

\author{
Anna Malkanova ${ }^{1,2 *}$, Andrey Zabrodin ${ }^{1,2}$, Evgenii Ponomarev ${ }^{2,3}$ \\ 1 Federal Research Centre "KSC SB RAS", 660036, st. Akademgorodok, 50, Krasnoyarsk, Russia \\ 2 Siberian Federal University, 79/10 Svobodny Ave., 660041, Krasnoyarsk, Russia \\ 3 V.N. Sukachev Institute of Forest SB RAS, 660036, st. Akademgorodok, 50/28, Krasnoyarsk, Russia
}

\begin{abstract}
The dynamics of fires in the territory of Eastern Siberia (the territory of the Lena River basin in the middle reaches) has been studied with the use of materials from retrospective satellite imagery. The dependence of the burnability of forests in the local territories of Eastern Siberia on the level of heat and moisture supply is shown. The range of the burnability index (the number and area of fires) for the study area under extreme drought conditions was revealed, confirmed by retrospective data. It is shown that potentially the average annual values of the number of fires can be 2.5 times higher than the current statistics. Based on the invariant NDVI and NDWI indices, a range of changes in the characteristics of post-fire areas has been identified, which indirectly determines the level of fire impact on vegetation and the humidification regime.
\end{abstract}

\section{Introduction}

The problem of forest fires is relevant all over the world. Over the past 25 years, satellite monitoring has made it possible to assess the scale of fire processes in the forests of Siberia [1-3]. This is important for forecasting fire regimes in certain subregions in changing climatic conditions [4-6]. In order to increase the reliability of such forecasts, the series of available instrumental data on wildfires should be expanded using available retrospective satellite imagery (Fig. 1) [7].

Episodic data on fires in Siberia can be found in the materials of Meteor satellites obtained in the 1980s (Fig. 1,1), and modern data from Terra/MODIS satellites can also be found (Fig.1.2). Based on a preliminary analysis of these materials, we formulated a hypothesis that forecasting the dynamics of the burnability and probable scenarios of fire regimes in the near future requires prolonged information about fires from sources such as reliable instrumental satellite observations since the early 1970 s.

The survey material for the 70-80th years of the last century on separate subregions of Siberia partially available according to the Landsat 4-5 data (https://earthexplorer.usgs.gov/) (Fig. 1.3).

The purpose of this research paper is to analyse the connection between the burnability and meteorological parameters on the example of Eastern Siberia (the middle part of the Lena River basin) based on the characteristics of the extreme season in 1986, as well as assessment of the level of wildfire effects on the vegetation cover and on the dynamics of the spectral characteristics of disturbed areas.

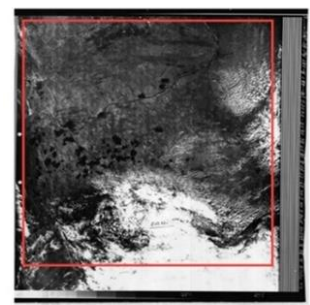

1)

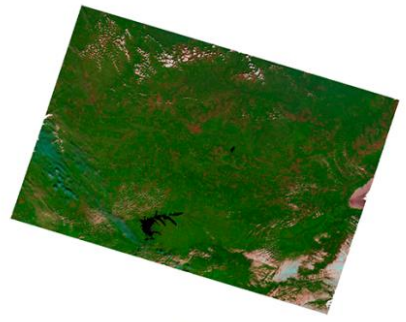

2)

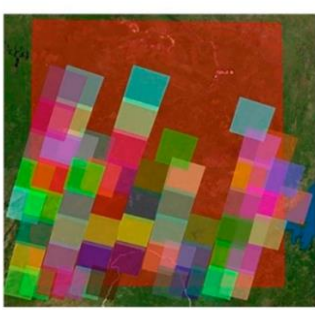

3)

Figure 1. Research area - the Lena River basin area in the middle reaches 1) Satellite image Meteor, 1986, 2) Satellite image Terra/MODIS, 2020, 3) Available satellite scenes Landsat 4-5 TM, 1986. The red square marks the border of the research area

\section{Source data and processing methods}

The research paper analysed data on post-fire areas recorded in Eastern Siberia (Lena River basin, 58-61 ${ }^{\circ}$ s.w., $118-$ $122^{\circ}$ v.d.) for the period 1986-2015 based on the materials of USGS [8] satellites Landsat 1-8 MSS/TM (Multispectral Scanner Sensor/Thematic Mapper) (Fig.2). Taking into account all available personnel, the percentage of coverage of the area of interest is not less than $65 \%$.

We studied groups of images obtained from Landsat 4-8 MSS C1 satellites for four periods: 1986, 1995, 2008,2015 in a combination of red $(0.61-0.76 \mu \mathrm{m})$, green $(0.54-0.57 \mu \mathrm{m})$ and blue $(0.48-0.51 \mu \mathrm{m})$ channels. The

\footnotetext{
* Corresponding author: malkanova@ksc.krasn.ru
} 
spatial resolution is $30 \mathrm{~m}$. The sample consisted of 12 images ( 3 images for each year). The total area of the research ground is 81.53 thousand $\mathrm{km}^{2}$.

With the help of the QGIS software package (Quantum Geographic Information System, version 3.20), a series of images was classified with training (the module in QGIS dzetsaka: Classification tool, https://github.com/nkarasiak/dzetsaka/).

After the classification, the areas of fire ranges and the indicator of burnability (Relative Burnt Area) were calculated as the ratio of the total area of fires per year to the forest area of the territory [8]:

$$
R B A=\frac{\sum_{i=1}^{n} S_{P_{i}}}{S_{g e n}},
$$

where $S_{P_{i}}$ is the area of a single fire, $S_{g e n}$ is the total area of the researched ground.

To assess the dependence of the burnability of the forests of the research area on the level of heat and moisture availability of the territory, the Selyaninov hydrothermal humidification coefficient (HTC) was calculated [9]:

$$
\mathrm{HTC}=10 \cdot \sum_{i=1}^{n} \frac{R_{i}}{t_{i}}
$$

where $R_{i}$ is precipitation in millimeters at $\mathrm{t}>+10^{\circ} \mathrm{C}$ for the $i$-th day of the season, мM, $t_{i}$ is the temperature value in the same period, ${ }^{\circ} \mathrm{C}, 10$ is the normalization coefficient.

To assess the characteristics of post-fire areas, the Normalized Difference Water Index (NDWI) was used, which indirectly characterises the moisture content in plants and soil [10]:

$$
N D W I=\frac{N I R-S W I R 1}{N I R+S W I R 1}
$$

where NIR $(\lambda=0.63-0.69 \mu \mathrm{m})$ and SWIR1 $(\lambda=1.55-1.75 \mu \mathrm{m})$ are the reflection coefficients measured in the specified wavelength ranges.

Additionally, the Normalized difference vegetation index (NDVI) was calculated to assess the state of vegetative vegetation covers for each season of the study period. In accordance with generally accepted criteria, we used the values of this indicator to assess the state of vegetation after fires, as well as for the general characteristics of the disturbance of the research area in certain seasons. The index was calculated based on the ratio:

$$
N D V I=\frac{N I R-R E D}{N I R+R E D}
$$

where NIR $(\lambda=0.63-0.69 \mu \mathrm{m})$ and RED $(\lambda=0.76-0.90 \mu \mathrm{m})$ are the reflection coefficients measured in the specified wavelength ranges.

Figure 2 shows an example of the distribution of vegetation indices NDVI (Figure 2.2) and NDWI (Figure 2.3) for 1986. To calculate this index, a standard methodology was used based on channel \#3 and channel \#4 for Landsat 1-7 or channel \#4 and channel \#5 for Landsat 8 [11,12].

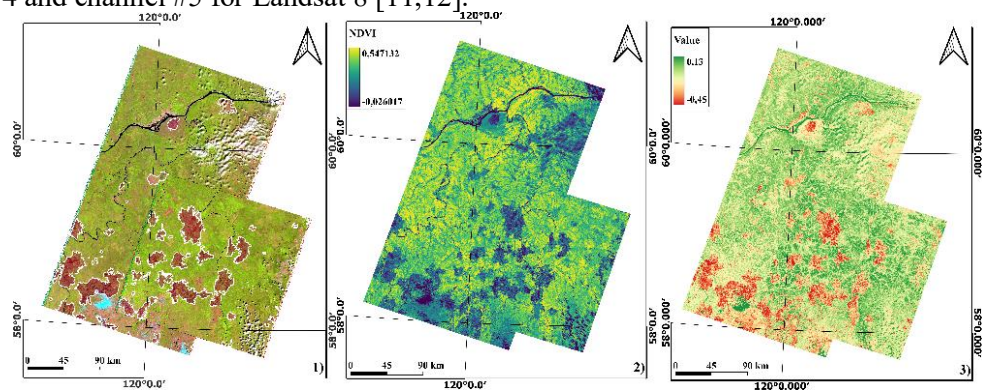

Figure 2. Landsat 1-5 MSK 1 survey for 1986: 1) Selected post-fire areas, 2) NDVI, 3) NDWI

\section{Results and discussion}

The level of extreme burnability of the studied subregion in the 1986 fire season was recorded (RBA=6.96\%). This indicator is significantly ( 10 times or more) higher than the average long-term level of burnability over the past 25 years, which was determined based on the materials of instrumental satellite monitoring of fires conducted in Siberia since 1995 (Table) [4].

Table. The results of processing satellite monitoring materials for the research area for 1986, 1995, 2008 and 2015.

\begin{tabular}{|l|l|l|l|l|l|l|}
\hline Year & $\begin{array}{l}\text { Number of } \\
\text { fires }\end{array}$ & $\begin{array}{l}\text { Area of fires, } \\
\mathbf{k m}^{2}\end{array}$ & $\begin{array}{l}\boldsymbol{R B A}, \\
\%\end{array}$ & HTC & $\begin{array}{l}\text { NDVI } \text { medium } \\
\left(\begin{array}{l}\text { Fires/ Not } \\
\text { damaged) }\end{array}\right.\end{array}$ & $\begin{array}{l}\text { NDWI mediun } \\
\text { (Fires/ Not } \\
\text { damaged })\end{array}$ \\
\hline 1986 & 66 & 5680.96 & 6.96 & 0.36 & $0.03 / 0.5$ & $-0.51 / 0.07$ \\
\hline 1995 & 20 & 156.76 & 0.19 & 1.09 & $0.3 / 0.6$ & $-0.33 / 0.15$ \\
\hline 2008 & 40 & 706.86 & 0.87 & 1.15 & $0.15 / 0.65$ & $-0.39 / 0.18$ \\
\hline
\end{tabular}




\begin{tabular}{|l|l|l|l|l|l|l|}
\hline Year & $\begin{array}{l}\text { Number of } \\
\text { fires }\end{array}$ & $\begin{array}{l}\text { Area of fires, } \\
\mathbf{k m}^{2}\end{array}$ & $\begin{array}{l}\boldsymbol{R B} \boldsymbol{A}, \\
\%\end{array}$ & HTC & $\begin{array}{l}\mathbf{N D V I}_{\text {medium }} \\
\text { (Fires/ Not } \\
\text { damaged) }\end{array}$ & $\begin{array}{l}\text { NDWI } \\
\text { (Fires/ Not } \\
\text { damaged) }\end{array}$ \\
\hline 2015 & 17 & 134.82 & 0.17 & 0.74 & $0.02 / 0.2$ & $-0.09 / 0.2$ \\
\hline $\begin{array}{l}\text { Average } \\
\text { without } \\
1986^{*}\end{array}$ & $26 \pm 13$ & $\begin{array}{l}332.81 \pm \\
366.77\end{array}$ & $\begin{array}{l}0.41 \pm \\
0.45\end{array}$ & $\begin{array}{l}0.99 \pm \\
0.25\end{array}$ & $\begin{array}{l}0.16 \pm 0.14 / \\
0.48 \pm 0.25\end{array}$ & $\begin{array}{l}-0.27 \pm 0.16 / \\
0.8 \pm 0.03\end{array}$ \\
\hline
\end{tabular}

* Data on the extreme burnability of the 1986 fire season are not included, as they have a significant excess relative to the average annual norm.

Prolongation of the fire chronology for 10 years made it possible to identify the burnability of the area of interest in the conditions of the extreme fire season of 1986. Compared with the subsequent period in such a season, the number of fires is 2.5 times higher, and the total area of fire damage (in terms of RBA) was up to $7 \%$. This allows us to make an assumption about the possibility of implementing extreme fire seasons (with a level of burnability $\left(\mathrm{RBA}_{\mathrm{EXTR}}=6.96 \%\right)$ significantly higher than the average long-term $(\mathrm{RBA}=0.41 \pm 0.45)$ ) in the region. This situation is likely to happen in the future, taking into account the changing climate and the increasing aridity of the growing season (according to indirect data of the HTC [4]).

An indirect assessment of the vegetation state of disturbed territories was obtained by analyzing invariant NDVI and NDWI indicators in comparison for post-fire sites and background (undisturbed) territories. It was found that after the fire, the value of the NDVI indicator decreases by up to $75 \%$ relative to the norm (undisturbed adjacent areas). This is consistent with the results of studies for other objects [13,14]. An additional characteristic was obtained based on the results of processing NDWI data, which characterizes the degree of moisture availability of sites. The results showed that after fires, the NDWI value changes upward, and relative anomalies compared to the background are $350 \%$.

\section{Conclusion}

We discussed the prospects of using archived satellite monitoring data to analyze the burnability and post-fire changes.

We found that the burnability correlates $(\mathrm{r}=-0.83)$ with the Selyaninov hydrothermal humidification coefficient (HTC), which decreased to 0.36 under the conditions of extreme drought in 1986 with an average longterm optimum for the region of $\sim 0.99 \pm 0.25$.

Significant deviations in the positive direction have the NDVI and NDWI indices. The standard values of these indices may affect the forecast of plant moisture supply. With values NDVI $=0.03 \ldots 0.71$ and NDWI $=0.07$, we have a high HTC index equal to 0.74 , which corresponds to low burnability $(\mathrm{RBA}=0.17)$ in 2015.

It is shown that in conditions of increasing the level of aridity of the growing season, a repetition of the scenario of the extreme fire season of 1986 is possible. At the same time, the average long-term indicators of burnability $(\mathrm{RBA}=0.41 \pm 0.45)$ can be significantly exceeded, as was observed in the example of 1986 , when the RBA reached $6.96 \%$.

The work was carried out on the topics of state assignment No. 0287-2019-0006 and No. 0287-2021-0040.

Acknowledgements. This work was performed using the subject of project of IF SB RAS no. 0287-2021-0008 and FRC KSC SB RAS no. 0287-2021-0040. This research was partly funded by the Russian Foundation for Basic Research (RFBR) and Government of the Krasnoyarsk krai, and Krasnoyarsk krai Foundation for Research and Development Support, no. 20-44-242002 ("Instrumental monitoring of physical properties and numerical modeling of the state of technogenically disturbed soils in Siberia").

\section{References}

1. V.I. Kharuk, E.I. Ponomarev, G.I. Ivanova, M.L. Dvinskaya, S.C.P. Coogan, M.D. Flannigan, Ambio. 50. pp.1953-1974. (2021) https://doi.org/10.1007/s13280-020-01490-x

2. S.A. Bartalev, F.V. Stytsenko, Lesovedenie. № 2. pp. 115-122. (2021)

3. A.I. Sukhinin, Sibir. jekologich. zhurn. 3. pp. 85-91. (1996)

4. E.I. Ponomarev, A.S. Skorobogatova, T.V. Ponomareva, Meteorology and Hydrology, 43, pp. $456-463$. (2018) DOI: 10.3103/S1068373918070051.

5. S.G. Conard and E.I. Ponomarev, Wildfire. 29. pp. 26-32. (2020) ISSN: 1073-5658.

6. W. Min Hao, B.L. Nordgren, A. Petkov, R.E. Corley, S.P. Urbanski, M.C. Reeves, L. Scott Baggett, Y. Balkanski, P. Ciais, F. Mouillot, C. Yue, Biogeosciences. 18. pp. 2559-2572. (2021)

7. A.V. Malkanova, A.N. Zabrodin, N.D. Yakimov, E.I. Ponomarev, Mat. III Vseros. nauch.-prakt. konf. «Aktualnye problemy obespechenija pozharnoj bezopasnosti i zashhity ot chrezvychajnyh situacij». Zheleznogorsk, 23 April 2021 g., Zheleznogorsk: SPSA GPS MChS Rossii, pp. 346-351. (2021)

8. V.V. Usenja, E.N. Katkova, S.V. Uldinovi, Lesnaja pirologija: uchebnoe posobie dlja studentov vysshih uchebnyh zavedenij po special'nosti «Lesnoe hozjajstvo», 264 p. (2011) 
9. G.T. Selyaninov, Gidrometizdat, In book: Zasuhi v SSSR, ih proishozhdenie, povtorjaemost $i$ vlijanie na urozhaj. pp. 5-30 (1958)

10. B.-C. Gao, Remote sens. Environ. 58. pp.257-266 (1996)

11. A. S. Cherepanov, Geomatika. 2. pp. 98-102 (2011) ISSN: 2410-6879

12. S.A. Bartalev, V.A. Egorov, V.O. Zharko, E.A. Lupjan, D.E. Plotnikov, S.A. Hvostikov, N.V. Shabanov. Sputnikovoe kartografirovanie rastitelnogo pokrova Rossii, 208 p. (2016)

13. N.D. Yakimov, E.I. Ponomarev, E3S Web of Conferences, 149, 03008 (2020) https://doi.org/10.1051/e3sconf/202014903008

14. T.V. Ponomareva, K.Y. Litvintsev, K.A. Finnikov, N.D. Yakimov, A.V.Sentyabov, E.I. Ponomarev, Forests , 12, p.994. (2021) https://doi.org/10.3390/f12080994 